УДК 33

DOI $10.21661 / \mathrm{r}-462121$

\title{
Инь Юн
}

\section{ОТНОШЕНИЯ МЕЖДУ КИТАЕМ, ЯПОНИЕЙ И РОССИЕЙ, ВЛИЯЮЩИЕ НА СЕВЕРО-ВОСТОЧНУЮ АЗИЮ В СОВРЕМЕННЫХ УСЛОВИЯХ}

Аннотация: отношения Китая, Японии, России играют важную роль в развитии Северо-Восточной Азии. Китайско-японско-российские отношения серьезно влияют на регионы Северо-Восточной Азии. Отношения между Китаем, Японией и Россией особенные в мире. Россия является политическим и экономическим центром в Европе, однако, это не влияет на отношения между мировыми державами. Автор утверждает, что данные отношения относятся к региональным, но при этом оказывают влияние на ситуацию между регионами, являются сложной и многосторонней составляющей, а не только специализируются в водной области. Отношения между Соединенными Штатами и Японией достаточно напряженные из-за проблем, связанных с Украиной, Россией и Европой. Россия выступила с заявлением, которое повышает значение экономических и политических связей с Азией. В данной статье анализируются современные отношениях Китая, Японии и России, а также российская стратегия «востока», проявляющаяся во все более сложных формах в северо-восточной Азии, и имеющая огромное значение для формирования экономической интеграчии в Северо-Восточной Азии.

Ключевые слова: китайско-японские отношения, китайско-российские отночения, Северо-Восточная Азия.

Yin Yong

\author{
CHINA - JAPAN - RUSSIA RELATIONS FOR THE INFLUENCE \\ OF THE NORTHEAST ASIAN REGION UNDER THE NEW SITUATION
}


Abstract: China, Japan, Russia, the three countries play an important role in northeast Asia. China-Japan-Russia relations are one of the important influence to the northeast Asian region. The relations among China, Japan and Russia are very special relationships in the world, with Russia's political and economic center in Europe, so it does not directly affect the relationships between the world powers. The author can only say that this belongs to the regional relations, but it has an influence across regions. At the same time, the relations are not simple relationships in a specific field, but a complex, multiple collection. The United States and Japan have increasingly tense relationships because of Ukraine problem between Russia and Europe. Russia issued a statement that attaches great importance to the economic and political ties with Asia. This paper has the analysis of the new situation of China-Japan - Russia relations, the analysis of Russia's strategy of «east» of increasingly complex forms in northeast Asia, which has a great significance to the formation of the northeast Asia economic integration.

Keywords: Sino-Japanese relations, China-Russia relations, Northeast Asia.

The triangular relationship among China, Japan and Russia is an objective existence

From the point of geography, China, Japan and Russia can be known as the northeast Asia countries. China and Japan are typical northeast Asia countries, Russia's political, economic and cultural center are in parts of Europe, but its far east territory is adjacent to China, Japan, Mongolia, north Korea and other countries, which plays an important role in northeast Asia. It's territory not only attached directly to the northeast Asia, but also actively involved in the affairs of northeast Asia, especially has many connections with China and Japan. China, Japan and Russia all can be called big countries, known as the northeast Asian region, which has important influence on northeast Asia regional affairs. They also have certain influence in the world, the relationship they produce also has a certain impact on the world. Recently, the problem due to the Ukraine increasing tensions between Russia and Europe, the United States and Russia issued a statement that attaches great importance to the economic and political ties with 
Asia. Historically often tensions between Russia and Europe, have the tendency of transfer center to Asia.

Three of bilateral relations between China and Japan, China and Russia,

Russian and Japan is objective existence

since the normalization of diplomatic ties between the two countries in 1972, relations between China and Japan is in the difficult situation, especially after the end of the cold war, the Japanese have become less dependent on the United States, which makes the further development of bilateral relations. Some problems currently existing in the development of relations between China and Japan, especially in recent years, historical understanding question territory, China and Japan relations have reached the lowest normalization. Whether it is «cold politics and hot economy» or «cold politics and warm economy», China and Japan relations are noticeable bilateral relations. The forecast problem of relations between China and Japan, Taiwan is now becoming visible. After Taiwan's democratic progressive party candidate Tsai Yingwen won election victory, the Japanese prime minister Abe and government officals publicly show welcome. In the south China sea issue, Japan as countries outside and the south China sea dispute parties, actively cooperates with the United States in the south China sea issue to China.

China-Japan relations stockpile of problems still exist, Japan again with new strategic confrontation.

Since the ninety's China and Russia have been developing towards the direction of good health, the leaders of the two countries after several meetings, put forward to the next century, China and Russia have common targets, namely, to establish strategic partnership oriented toward the 21st century. In April 1996, China、Kazakhstan, Kyrgyzstan and Tajikistan signed agreements in Shanghai, the Shanghai cooperation organization was established. The addition of Uzbekistan in June 2001 expands and strengthens the Shanghai cooperation organization. On October 14, 2004 in Beijing, China and Russia signed the Joint Declaration and the Good-neighborliness and 
Friendly Cooperation Treaty Implementation Summary (2005-2008). The relations between the two countries had peaked in 2010 and opened the oil pipeline between the two countries in January 1, 2011. Xi Jinping, the chairman made a special trip to attended the 2013 Sochi Olympics opening ceremony last month, the second year in a row to Russia as his first. Both sides is in the best stage in the history of China-Russia relations.

Since the second world war to 2014, the problem of «four northern islands» territorial disputes Between the two countries has deteriorated the relationship between the Russia and Japan. After aircraft shot down event in Malaysia, Japan made sanctions on Russia, which caused a strong reaction of the Russian government. On July 29, the Russian foreign ministry said in a statement that the additional sanctions on Russia is not friendly and have no vision, will be detrimental to the development of bilateral relations. Said in a statement, the Japanese that shows its commitment to develop relations with Russia's intention is hypocrisy. On August 5, the Japanese cabinet approval on Russia's further sanctions on the same day, the Russian foreign ministry said that due to the additional sanctions on Russia, the two countries was held at the end of August to solve the problem of «four northern islands» disputed territory vice ministerial consultations will be postponed. Analysts said that Japan's sanctions against Russia is in a dilemma: the European and American countries under the background of sanctions against Russia, Japan as America's Allies, had to stand in favor of European and American countries. On the other hand, Japan wants to import resources in Russia through negotiation to solve the problem of «four northern islands» territory. Aircraft shot down event in Malaysia, the relationship between the Russia-Japan deteriorate even further.

The triangular relationship among China, Japan and Russia keep cooperation and contain coexistence

Russia keeps good relationship with China all the time and at the same time, it also actively develops relations with Japan. China-Japan relations with Russia, ChinaRussia relations is the least problem and the most rapid development of bilateral rela- 
tions. China-Japan and Russia-Japan relations both have territorial disputes. The diaoyu island question seriously affect the relations between China and Japan, which made the China-Japan relations get the lowest normalization. «Four northern islands» issue crisis, Japan's economic sanctions against Russia, Ukraine, etc., has serious influence on the Russia-Japan relations. Japan develop Russia-Japan relations to contain China, good Russia-Japan relations will help Japan achieve political superpower ambitions. At the same time, Russia use Japanese restricting China's strategy to develop relations with China. However, China's development of bilateral relations is not to restrict foreign factors, because the Russia-Japan relations are difficult to solve the problem, which are not controlled by the China. Russia has rich natural and energy resources, China and Japan are energy importers, which want to import oil and gas from Russia. First of all, to import Russian energy issues, China and Japan is in a state of mutual competition, instead, Russian interests from the winner. Although Russia's economic strength is relatively weak, Russia is rich in natural energy resources and broad market, must pay attention to the foreign object. China and Japan. According to the domestic data, China's oil consumption in 2010 is 439 million tons, in 2011 is 470 million tons, and in 2012 is 493 million tons. China produced oil 200 million tons every year, the external dependency of crude oil in 2012 was $56.42 \%$, for the historical peak. Therefore, the stable supply of energy and strengthening the cooperation with energy producer have been an important issue in the economic development of China. Japan is a country of extreme scarcity resources, and such is energy. The Japanese government ministry of economy of Japan's energy and natural resource management agency, said in January 2014, the Japanese from Arab countries and Iran in the Middle East oil ratio has reached $83.2 \%$ of Japan's total oil imports. In this number, the Arab oil ratio is $77.9 \%$,which means that Japan's domestic demand more than three-quarters of the oil from the gulf co-operation council (GCC) countries and Iran. In order to disperse rely too much on Arab oil imports, Japan attaches great importance to establish energy diplomacy with Russia.

Second, due to economic sanctions against Russia, the European and American countries promoted the Russia's energy exports to east Asia region. Russia is a resource 
mainly exports, crude oil, oil products, natural gas accounted for more than two-thirds of exports. The EU's trade accounted for more than half of the fast to Russian trade, exports to Europe is west of the west Siberian oil, natural gas is given priority to, the trend of western natural gas and oil has decreased in recent years. Far east natural gas and oil are considered, which becomes Russia's new export channels. Among Russia's trade partners, China accounts for the first bit, Japan accounted for no. 8. The Russian government wants to use the vigor of rapid economic growth in northeast Asia, China and Japan are essential. Bilateral trade between Russia and China will hit a record $\$ 90$ billion in 2014. China is already Russia's main trading partners, and Russia also on China's trade competitors ranked into the top ten. From 2002 to 2013, bilateral trade volume increased from $\$ 12$ billion to $\$ 89.2$ billion. Russia-Japan trade reached $\$ 33.2$ billion in 2013, Japan is the seventh largest trade partner, before the United States, Turkey, France, Italy. So far, Japan invest up to $\$ 2.7$ billion in the stock.

In the Russian oil pipeline to the Asia-pacific region, the two countries started a game of Russian energy. Since 2002, the Russian oil pipeline there are north and south two solutions, the downtown namely from Angarsk to Daqing oil pipeline Ann big line, northern namely from Angarsk to Nakhodka pipeline Anna line. Japan puts interest in the Russian far east oil to spread the risk on Middle East oil imports. Japan decide to step in oil pipeline project and strive for pipeline repair to Nakhodka in Russia's far east, namely the northern line. Because of the Japanese intervention, pipe have complex problems. Japan can't wait to keep out of the China-Russia oil pipeline, on the one hand, to weaken the consolidation and development of the China-Russia strategic partnership of coordination. On the other hand, Japan attempt to through the cooperation with Russia in the field of energy, improve the influence of Japan in the far east.

The triangular relationship among China, Japan and Russia influence on northeast areas in China

In the past year, China and Japan and Russia bilateral interaction is very close, which adds a new variable to the relations between China and Japan. Not only should attach importance to the United States «to return to the Asia-pacific» and «rebalancing strategy» impact on China-Japan relations, but also should pay attention to Russia's 
strategy of «eastward» impact on China-Japan relations. To develop northeast Asia policy, Russia should pay attention to find two balances: the first is to actively participate in political cooperation of northeast Asia to ensure that Russia is not excluded in regional affairs, and to ensure that this participation does not harm the security and stability of east Siberia and the far east Russia; The second is to actively participate in both of the northeast Asia economic cooperation to ensure that the eastern Siberia and YuanDongSuo need of market, capital, technology and labor, and to prevent the region's economy entirely from Russia, become subservient to «resource» of the economy in northeast Asia. Russia in northeast Asia policy, is becoming more and more active more and more active, more and more comprehensive. Russia completed transition from the bystander to participant, it is from the ordinary participants to key participants. From the above Russia policy in northeast Asia, The relationship between value and northeast Asia mainly because between China and Russia has more than 4000 kilometers of the adjacent boundary, China's heilongjiang province has 15 areas which are confirmed as the two countries border crossings. The trade between China and Russia have no obvious change, but with the help of two governments and enterprises, China and Russia trade will have greater prospects for development. Second, the two countries develop economic positioning as the main state policy, The status and situation of the two countries are similar to the world. It is the key and the foundation to Develop relations with China,even the entire Asia-Pacific region. Russia is also adjacent with Japan sea, Japan-Russia border trade development centered on the Japanese island of Hokkaido actively. Also actively promote energy between Russo-Japan negotiations and cooperation.

China, Japan and Russia are northeast Asia regional powers, they should bear the corresponding power of the responsibility and obligation, hostility will damage the interests of all countries. However, since Japan's Mr Abe's government took office, for developing, in northeast Asia and play an important role in the world, it not only has not cooperation policy, but rather through the America-Japan alliance, and the United States «return to Asia» strategy of containment and contain China. Japan unilaterally 
declared nationalization diaoyu islands regardless of the opposition to China's territorial disputes with China. On the energy cooperation between China and Russia, it poses a hostile attitude to compete with China, destroying the energy cooperation between China and Russia. In the economic globalization today, relations between China and Japan to strengthen cooperation is accord with the public opinion and keeping pace with the world. Russia also should be the correct developing relations with China and Japan, it doesn't make an issue of on China-Japan relations to seek their own interests.

In a word, China, Japan and Russia should strengthen the cooperation between, discharge dysfunction and jointly promote northeast Asia economic integration. This requires the three leaders and politicians with vision, a more reasonable solution to the problem of history and national, in mutually beneficial and win-win mentality to deal with the crisis and difficulties.

Инь Юн - доцент Академии общественных наук Провинции Хэйлунцзян, Китайская Народная Республика, Харбин.

Yin Yong - assistant professor at Heilongjiang Academy of Social Sciences, the People's Republic of China, Harbin. 